Article

\title{
Trump as Mirror for the Church: Death and Despair, Hope and Resurrection of the Church
}

\author{
Daniel M. Bell Jr. \\ Religious Studies Program, Lenoir Rhyne University, Hickory, NC 28601, USA; dmbelljr01@gmail.com
}

Received: 10 February 2020; Accepted: 25 February 2020; Published: 27 February 2020

\begin{abstract}
The election of Donald Trump inaugurated a wave of anxiety-bordering-on-despair among various peoples hoping for another, better world. This paper considers whether Trump deserves such acclaim in the sense that Trump is at best a symptom or cipher that can be approached by heeding Martin Luther's observation that our politicians reflect who we are. To make this argument first I draw upon the work of Andrew Bacevich to suggest a certain continuity rather than apocalyptic break in recent American politics. Then I ask what the production of such politicians and politics says about American Christianity, which is far more frightening than the fleeting ascendancy of a mere Trump. In particular, using the National Study of Youth and Religion I suggest that the church in America suffers from a widespread failure of formation in the faith. What are we to make of this failure? Whence cometh hope? Building on Ephraim Radner's interrogation of the divided church and on Jonathan Lear's exploration of radical hope in the wake of cultural devastation, I will suggest both a theologically appropriate despair and also a hope for emergent forms and practices of faith capable of resisting the darkness of these times.
\end{abstract}

Keywords: hope; despair; Donald Trump; Andrew Bacevich; Jonathan Leer; Ephraim Radner; Stanley Hauerwas; National Study of Youth and Religion

\section{Introduction}

Can any feeling person deny that with the election of Donald J. Trump as president of the United States of America something fundamental seems to have shifted, broken, given way? His ascendancy and reign have unleashed a tidal wave of furious reflection suggesting the center no longer holds and things are falling apart. Indeed, the spirit of Yeats seems to have infused many a public intellectual as the magnitude of the disaster toward which we are slouching, led by this not-exactly-blond beast, is cast in apocalyptic proportions. The end of liberalism! Civil war! A new (white supremacist) fascism! As Andrew Bacevich observes, "Take resistance rhetoric at face value and you might conclude that Donald Trump is indeed the fifth horseman of the Apocalypse" (Bacevich 2018).

Not since the (s)election of George Bush, when the universal cry seemed to be "Empire!," have times seemed so dark. Thus, Alain Badiou, reflecting on Trump's victory, speaks of "the horror of a deep night" and "this disaster" (Badiou 2019). The Call for Papers for this special edition of Religion captures the spirit of this time as well as anyone when it invokes Hannah Arendt's reference to "dark times," the prospect of the erasure of liberal democracy and the Apocalypse.

As disturbing as Trump is, however, in what follows I will push back against the narratives that attribute this present darkness to Trump, that grant Trump such earth-shaking and age-shaping power. Whatever is going on, it is not the case that we have suddenly moved from an age of hope and enlightenment (notwithstanding how much Obama might desire to be remembered in such a way) to apocalyptic disaster (notwithstanding how much Trump might aspire to be cast as that significant, that powerful, that great). Rather, Trump, always the underachiever and poser, is at best a symptom or cipher of a more frightening reality, a more disturbing truth. 
We can begin to uncover this more disturbing truth by picking up on Martin Luther's insight that we get the politicians we deserve (Luther 1962); that is, our politicians reflect who we are. Taking this as my starting point and following Andrew Bacevich's more contemporary analysis, I will suggest that Trump stands firmly within trends in recent American politics and culture. Trump is not the sudden and unexpected eclipse of Obama's sun. Even his most noxious policy moves do not mark a fundamental, apocalyptic aporia in American politics. No aberration, Trump is but a representative of American character and culture in the early 21st century.

If this is true, this is deeply disturbing and makes the darkness that envelopes us even darker. Yet we are not done plumbing the depths of these dark times, for there are unfortunately more folds to this abyss. In particular, for the theologically inclined, we might ask—still following Luther's logic-what Trump's election reflects of the character of American Christianity? After all, as has been widely recognized, American Christians are some of Trump's most fervent supporters. In other words, if Trump is not a singular disruption of American politics but a reflection of American politics and culture, then perhaps his elevation can be a useful mirror to the church, prompting reflection on the nature of American Christianity.

In what follows, I will do exactly that, arguing that Trump's election reflects a certain weakness or failure of American Christianity, a weakness or failure I explore primarily through the lens of the National Study of Youth and Religion. This study suggests that the church in America suffers from a widespread failure of formation in the faith.

Dark times indeed. With that which is supposed to be a beacon of hope-the church, Christianity - preferring the darkness, the darkness seems nigh insurmountable. The temptation to despair is great. What are we to make of this failure? Do we despair? Whence cometh hope?

Building on insights drawn from Ephraim Radner's interrogation of the divided church and on Jonathan Lear's exploration of radical hope in the wake of cultural devastation, I will suggest both a theologically appropriate despair and also a hope for emergent forms and practices of faith in America capable of resisting the darkness of these times.

\section{What Does Trump Signify? ${ }^{1}$}

Reflecting on Trump's election, Andrew Bacevich says it about as well as anyone: “Then came the Great Hysteria. Arriving with a Pearl Harbor-like shock, it erupted on the night of November 8, 2016, just as the news that Hillary Clinton was losing Florida and appeared certain to lose much else besides became apparent" (Bacevich 2018). Such was the birth of the sensibility that Trump represents a great fissure or break with what went before.

Bacevich's choice of the label "Great Hysteria" reflects his conviction that in fact Trump does not represent a substantive break with or within American politics and culture. Trump did not fall from heaven (or rise from some more sulfurous elsewhere) like a stone, shattering a more amicable and virtuous politics.

\subsection{Business, Etc. As Usual}

While it exceeds my expertise as well as the parameters of this essay to offer a full-blown account of Trump's continuity with existing trajectories in American politics and culture, perhaps a brief, suggestive sketch will suffice to clear the path for my argument.

Surely on matters such as taxes and government regulation, the environment, gender politics and abortion, etc., it is not difficult to see nor particularly controversial to suggest that Trump's policies and positions fall clearly within the main trajectories of Republican politics. Even so, might not the

1 Rowan Williams warns against using people as symbols because it is reductive and finally dehumanizing. In what follows I believe I follow the spirit of his warning to the extent that I am resisting simply "blaming Trump," refusing to use him as a scapegoat and instead prompting a kind of self-reflection. (Williams 2002, pp. 61-74). 
"break" narrative hold in light of Trump's much more high-profile positioning on race, immigration and foreign policy?

Especially when contrasted with the fact that he assumes office after Barak Obama, it might be tempting to cast Trump as embodying a fundamental interruption or break with American politics around race. After all, as Michael Eric Dyson has said, "Whether he wishes to be or not, Donald Trump is the epitome, not only of white innocence and white privilege, but of white power, white rage, and, yes, even of white supremacy" (Dyson 2017). The break narrative depends on comparing two persons instead of their politics. When considered in context, the break disappears as during Obama it is at least arguable that the US did not live in a racial Mecca, and that race relations may have actually deteriorated (Bacevich 2018). This is hinted at by Dyson insofar as he calls Trump the "epitome." As such, Trump is not a break but the culmination of racial trajectories in American politics, trajectories whose lines are very clear-from the infamous Republican "Southern Strategy" of the 1970's and 80's, through the Democrat Al Gore's infamous (and often forgotten) use of Willie Horton against his Democratic opponent in the 1988 presidential primaries (a tactic later replicated by the Republican candidate), to Joe Biden's opposition to busing and school integration, to the Clintons' role in the development of "the new Jim Crow," that is, the mass incarceration of African Americans. ${ }^{2}$

Even with regard to matters of immigration, where at first glance Trump appears as a stark and obvious break with the general trajectory of American politics, appearances can be deceiving. For example, although both the right and left are reluctant to admit it, Obama oversaw a massive crackdown on illegal immigration far in excess of his Republican predecessor, and arguably at least every bit as rigorous as what Trump is actually doing. ${ }^{3}$ The U.S. Congress, for all intents and purposes, closed the border with Mexico in the 1980's. Trump's talk of a wall falls squarely in line with that policy, and we should not forget that it was Bill Clinton's 1994 border patrol strategy, "Prevention Through Deterrence," that closed urban passages and forced migrants to much more dangerous desert/wilderness corridors. As horrible as separating children from parents at the border may be, it is not self-evidently worse than deliberately driving migrants into deadly deserts and the hands of ruthless human smugglers.

Foreign policy and trade is the third area where Trump is most often cast as representing a break with the broad consensus of American politics. The kernel of truth in this claim lies in the fact that Americans are living through a period of transition. As Andrew Bacevich notes, what we are currently experiencing is a reaction to the failure of expectations nurtured by post-Cold War politics and politicians of both political parties. The promise of the post-Cold War politics in America was that corporate capitalism would create vast wealth, which would be secured by US military might and managed by a US president who functioned as a kind of global overseer. He writes,

[M]y sense is that many Americans have an inkling that history of late has played them for suckers. This is notably true with respect to the post-Cold War era, in which the glories of openness, diversity, and neo-liberal economics, of advanced technology and unparalleled US military power all promised in combination to produce something like a new utopia in which Americans would indisputably enjoy a privileged status globally. (Bacevich 2018)

While this vision of globalization enriched some, these expectations have gone mostly unfulfilled as most Americans have been left with "grotesque inequality, worrisome insecurity, moral confusion, an epidemic of self-destructive behavior, endless wars, and basic institutions work poorly if at all" (Bacevich 2018).

Trump gives voice to these unmet expectations and so marks a change in US foreign policy and trade in that sense. Moreover, Trump is a change just to the extent that his foreign policy is ill-informed and impulsive, what Bacevich calls foreign policy by presidential whim (Bacevich 2018).

2 See (Alexander 2010).

3 Admittedly, there are conflicting reports on these matters but the existence of the conflict actually supports the claim that Trump does not embody a drastic break with American politics. See (Marshall 2016; Wolf 2019). 
But he is far from embodying a break with the fundamental orientation of American politics. His actions and policies may reflect a change from a utopian to more bellicose globalism, they may reflect a nation struggling with its decline as the premier hegemonic power, but they are not the actions of an isolationist, an anti-capitalist, or of one who wishes to delink from the global economy.

In the end, Trump signifies a continuity, even an intensification, of trajectories in American politics. Indeed, far from a break or apocalyptic rupture, he is entirely the product or consequence of American politics and culture. He is a symptom, not a sui generis source.

\subsection{America First, Always}

The way in which Trump is properly viewed as entirely in continuity with American politics, albeit at a time of transition (and perhaps decline) is nowhere clearer than when one considers the theme of his administration: Make America Great Again. While the language may change, the underlying political impulse and orientation is not new. (Even the isolationist pretense is not new. Consider early 20th century American politics.) America First has always driven American politics. The vision of globalization that drove the post-Cold War American political consensus from 1989 to 2016 never meant others were to be placed ahead of or even granted a status on par with US interests. It was never about sharing the wealth with others; it was always about sustaining American accumulation and consumption.

When I hear pundits and others talk of Trump as a rupture or break with American politics, I recall President Bill Clinton's speeches to the AFL-CIO in 1992 and 1997. In making the case for trade agreements he was then negotiating, Clinton asserted that US workers had been mistreated in the 80s and that these agreements would help them, increasing both the number of jobs available to them and their wages. (Presidential pandering to working class grievance is not new.) "America is back!" he declared to the assembled workers. He went so far to state that these agreements are about ensuring $4 \%$ of the world's people get to keep $22 \%$ of the world's wealth (Clinton 1997).

Make America Great has always been America's motto. It is the implicit justification of the exceptionalism that underwrites its imperial aspirations, its self-assigned destiny as the indispensable nation (Bacevich 2002).

\subsection{The Ugly American Hiding No Longer}

At most, Trump represents an intensification of trajectories in American culture and politics. He is a president well-suited to the Age of the Spectacle, where celebrity and appearance trump achievement and truth (Debord 1995). Admittedly, the spectacle that is Trump is a stylistic break with traditional presidential politics. Trump's narcissism, dishonesty and, in particular, his vulgarity most definitely break with traditional canons and precepts of late 20th century presidential decorum, but this stylistic breach does not embody a fundamental disruption of American politics nor is it at odds with the atomistic individualism of American culture.

On the contrary, this coming out of the "ugly American" might best be understood as the logical outgrowth of the maturing of America as a capitalist state. It is the natural, if perhaps a bit belated, concomitant of the coming out of savage capitalism - that late 20th century turn in capitalist development that saw it drop any pretense of humanism, of any concern for virtue and the common good. In this regard, I recall Trump's remark to a talking head who questioned his comity with Putin, whom the talking head referred to as a "killer." Trump replied, "You think our country's so innocent?" (Tatum 2017). Trump represents a politics that no longer bothers with wrapping "America First" in 
the pretense of a commitment to any sense of the common good. Shedding the genteel facade, the sentiment is now "What is good for America and to hell with the world." 4

In the end, Trump is not a dramatic break in American politics but the product or consequence, symptom even, of long-standing trends or trajectories in American politics and culture. He is the product of changes that have been underway apart from him and that we must face, whether he occupies the White House or not.

\section{Christianity in the State We Are In}

Trump is not an intrusion or interruption of American politics and culture but its product, its consequence. Which is another way of saying, as Bacevich does, that he is us (Americans): "Like it or not, the president of the United States embodies America itself. The individual inhabiting the White House has become the preeminent symbol of who we are and what we represent as a nation and a people. In a fundamental sense, he is us" (Bacevich 2018).

Some might object to this characterization, especially with regard to Trump. After all, it is commonplace to argue that Trump's election was really the result of a small group of angry white working-class people residing in a few mid-western/rust belt states. For all the comfort this tale might provide some, it is false. The vast majority of Trump's support did not come from angry white working-class folk. Rank-and-file Republicans along with millions of others from across the country and across economic strata elected Trump.

Prominent among these supporters are Christians. Indeed, it has been argued that Christians basically handed Trump the presidency, with $81 \%$ of the white evangelical vote going to Trump, a higher level of support than either Ronald Reagan or George W. Bush ever received (Gerson 2018).

\subsection{For Trump in God's Name, or Not: Realism and Gnosticism}

What does this say about American Christianity? What does it say about American Christianity that it has largely thrown its support behind a person whose background and beliefs, Michael Gerson, a noted evangelical and former speech-writer for Bush, says "could hardly be more incompatible with traditional Christian models of life and leadership" (Gerson 2018). Indeed, Gerson goes on to suggest that Trump's values-his materialism, his hatred of "the other" and especially those deemed "weak" - more closely resemble those of Nietzsche than Christ. ${ }^{5}$

On one hand, it stands as an indictment of the way many American Christians understand the interface of faith and politics. In mainline traditions, the dominant political theology has been decidedly realist, with its logic of the lesser evil. Few of the laity know Niebuhr, but they have absorbed the Niebuhrianism of church leadership and so conceive of responsible Christian political action in terms of choosing lesser evils. The language is different in evangelical camps, but the logic is similar. Evangelicals embrace the lesser evil by means of a "vessel" theology. Drawing on the biblical precedent of God using notorious sinners and non-believers to advance God's cause, evangelicals defend their embrace of Trump as if he were another Cyrus or David. ${ }^{6}$

On the other hand, it suggests that many Christians see no relation between their faith and politics. Already more than a half century ago, during another dark time of political struggle, or perhaps just an earlier phase of this same dark time, Martin Luther King, Jr. pointed out the pervasiveness of a faith in

4 Even this is not entirely novel with Trump. As Tariq Ali said shortly after the invasion of Iraq in 2002, commenting on the Bush administration: "American imperialism has always been the imperialism that has been frightened of speaking its name. Now it's beginning to do so. In a way, it's better. We know where we kneel." (Barsamian 2002).

5 (Gerson 2018) It should be noted that there has been a renaissance in Nietzsche studies over the last generation and much of it challenges what has become a stereotypical presentation of Nietzsche as a moral monster. Whether or not Gerson's comparison ultimately is fair to Nietzsche is beside the point, however. His point is the moral distance between Trump and Christ. I will say, however, that however hard and even brutal Nietzsche's "master morality" might be, I do not see him reveling in the suffering of others in the way Trump and some of his supporters seem to. See (Serwer 2018).

6 See (Block 2018) (Cohen 2019). 
America that "remained silent behind the anesthetizing security of stain-glassed windows," committed to "a completely otherworldly religion which makes a strange, un-Biblical distinction between body and soul, between the sacred and the secular." ${ }^{\prime 7}$ In complementary fashion, Harold Bloom suggests that American Christianity is a species of Gnosticism, faith reduced to information received by a self who through such knowledge is freed from nature, time, history, community, and other selves. ${ }^{8}$ This disconnect between faith and political life is borne out by polls that consistently report that religion does not play a major, determinative role in most American Christians' political choices. ${ }^{9}$

Previously I argued that Trump did not represent a break with American politics and culture. It appears, instead, that the break Trump does signify (but did not initiate) lies within American Christianity. What has happened in American Christianity that allows persons of faith to embrace the values of Nietzsche (to follow Gerson) either in the name of God or without any reference to God at all?

\subsection{The National Study of Youth and Religion}

For an answer, consider the National Study of Youth and Religion, as reported in the work of Christian Smith and Kenda Creasy Dean (Dean 2010) (Smith and Denton 2005; Smith and Snell 2009). The NSYR involved studying and interviewing several thousand young persons over a period of seven years (2001-2008) from a broad spectrum of Christian and Jewish faith communities. The study is interesting on many levels, but especially for a glimpse into the nature of the faith that is proclaimed and practiced by Christian churches in America.

Perhaps the most immediately striking fact revealed by the study is that, contrary to conventional wisdom, American teenagers and youth are not in rebellion against Christianity and the church. While it is true that young adults show a tendency to distance themselves from the particular forms of their parents' religious observance (perhaps loosening ties and attendance with their "home" congregation) as part of their struggle for independence and identity differentiation, (Smith and Snell 2009) as a whole they are not hostile toward religion. To the contrary, both teenagers and young adults report that they are generally positively inclined toward religion and toward the congregations they know (Smith and Snell 2009). Nor do they think that the church is full of hypocrites or doubt the integrity of the adults who worship there. Even the tagline that has become popular in some media and ecclesial circles that youth and young adults are "spiritual but not religious," that is, turned off by institutionalized religion, is debunked as largely a myth (Smith and Denton 2005; Smith and Snell 2009). On the whole, American youth are content and conventional. As Smith observes, countering the commonplace notion that youth are restless, rebellious, and alienated from religion:

[T]hat impression is fundamentally wrong. What we learned by interviewing hundreds of different teenagers all around the country is that the vast majority of American teenagers are exceedingly conventional in their religious identity and practices. Very few are restless, alienated, or rebellious; rather, the majority of U.S. teenagers seem basically content to follow the faith of their families with little questioning. When it comes to religion, they are quite happy to go along and get along. (Smith and Denton 2005)

7 (King 1964, p. 90) Lest one think that King's observations are outdated, as I write this I have before me a 2012 petition from the Mississippi Annual Conference of my church requesting that the mission statement of the denomination be changed to prioritize "the salvation of souls" while relegating "the transformation of the world" to secondary status.

8 (Bloom 2006, p. 36) For a slightly more contemporary sociological assessment that in its main contours complements Bloom's analysis, see (Wolfe 2003).

9 Making sense of the polls and research on this is difficult, not the least because of rather sensational headlines that tend to conceal more than they reveal (see the Barna report that follows, as an example) and because of a penchant to see religion as an independent variable in American political behavior instead of seeing it embedded in the intersection of class, race and gender. (The article by Hirshle below addresses this.) Nevertheless, wading through these difficulties, it is clear that religion is not a significant source of political guidance for most Christians. See (Pew Research Center 2003; Barna Group 2016; Hirschle et al. 2009) 
At first glance, this appears to be good news and perhaps something of a relief to those who are fretting over what to do (and where to get the funds) to change their congregational life so that they are more appealing to what was assumed to be an alienated and antagonistic younger generation. But as Smith and Dean continue with their analysis, cause for relief quickly disappears as it becomes clear that the operative word for the relation of youth to religion is "indifference." 10 As Kenda Creasy Dean writes, "The bad news is the reason teenagers are not hostile toward religion: they just do not care about it very much. Religion is not a big deal for them" (Dean 2010). It functions as a kind of benign, unobtrusive background that evokes little thought or concern. The problem, Smith says, is not youth hostility but "benign 'whateverism'" (Smith and Denton 2005).

It would be thoroughly unsurprising if our first response to this revelation was to lament the failure of the youth to embrace the faith that is proffered to them by the church. Or perhaps in a more charitable vein, we might acknowledge our failure to teach and communicate the faith well. But both of these responses reflect a failure to grasp the lesson of the NSYR. Recall that the study reveals youth to be utterly conventional. By and large, they are not rejecting what the church teaches. To the contrary, they are following in the footsteps of their elders, especially their parents.

In other words, the indifference of youth is not the result of a failure to listen or a failure to teach. Rather, it is indicative of the success of contemporary Christian proclamation and practice. As Dean puts it in a passage worth quoting at length,

Overall, the challenge posed to the church by the teenagers in the National Study of Youth and Religion is as much theological as methodological: the hot lava core of Christianity - the story of God's courtship with us through Jesus Christ, of God's suffering love through salvation history and especially through Christ's death and resurrection, and of God's continued involvement in the world through the Holy Spirit - has been muted in many congregations, replaced by an ecclesial complacency that convinces youth and parents alike that not much is at stake.... The problem does not seem to be that churches are teaching young people badly, but that we are doing an exceedingly good job of teaching youth what we really believe: namely, that Christianity is not a big deal, that God requires little, and the church is a helpful social institution filled with nice people focused primarily on "folks like us" which, of course, begs the question of whether we are really the church at all. (Dean 2010)

\subsection{Moralistic Therapeutic Deism}

Dean's remark about "whether we are really the church at all" is a reference to what the Smith identifies as the message of North American Christianity: Moralistic Therapeutic Deism. There are five tenets of this faith:

1. A god exists who created the world and watches over it.

2. God wants people to be good, nice, and fair to each other, as is taught by the Bible, most world religions, and by our intuitions.

3. The central goal of life is to be happy and feel good about oneself.

4. God is not involved in my life except when I need God to resolve a problem.

5. Good people go to heaven when they die. ${ }^{11}$

Much could be said about this theologically. For the purposes of this essay, I wish to highlight that it clearly reflects the instrumental character of contemporary Christian proclamation and practice,

10 Recall that this study did not focus only on liberal, mainline churches. It included Mormons, evangelical white churches and black churches as well. Hence the results below are not limited to the liberal churches. The study did reveal a difference in levels of commitment between churches. Mormons had highest percentage of devoted, followed by evangelical white and black churches, followed by mainline Protestant, then Catholic, then Jewish, then those who identified as non-religious.

11 (Dean 2010, p. 14) I amended the "intuitive" reference based on Christian Smith's work. 
which in its various forms presents Jesus as serving our wants and needs instead of radically changing our lives (including our wants and needs) so that they conform to the holiness of God, so that they are marked by the love and obedience of God. Much contemporary North American Christianity seems to be saying that Jesus is determined to see that our will be done.

Which, in turn, naturally gives rise to indifference. After all, once the church concedes that the individual's needs or wants are sovereign - that the central goal of life is to be happy and feel good about oneself-then Christ and the church are importantly only to the extent that they are able to serve those needs and wants.

This means that the church makes no difference. What it offers is not good news. What it offers is not really news at all. Rather, it is just more of the same. What we say about Jesus suggests that we are just another service provider, entertainer, (remedial) morals instructor, cheap therapist, poor person's country club, and so forth. ${ }^{12}$ We are just another competitor, another brand, on the market of meaning, interpersonal warmth, life-lessons, etc.

In the end, much contemporary American Christianity fails to offer good news. What it offers is, for the most part, not repelling but neither is it compelling or inviting. Said differently, as the NSYR suggests, this god is too small to hold our attention, to inspire commitment, to drive action or instill purpose and direction. In short, this is a rather benign god who neither calls nor offers much.

\subsection{Ethics?}

This paves the way for the kind of moral disconnect, via realism or Gnosticism, embodied in Christian support for the politics and culture represented by Trump. This moral disconnect is evident in the results of the NSYR. In a compelling study of emerging adulthood, Lost in Transition, Christian Smith presents the findings of the NSYR on a range of topics, from morality to sexual practice to civic and political engagement (Smith et al. 2011).

With regard to moral values, the portrait that emerges is troubling. Most young people do not think much about morality. Thus, what they do say tends to be inarticulate, inconsistence and even incoherent. When asked, many could not even name a moral dilemma. Among those who did, many named something trivial ("Do I purchase a second litter box for a pet that urinates outside its box?") while others relegated morality to the margins of life, to issues that had little impact on their lives-like murder and bank robberies.

The moral vision of American young adults is a species of atomistic individualism. ${ }^{13}$ They believe it is wrong to judge others, by which they mean it is wrong to assess or evaluate others morally. This arises not so much out of an abiding commitment to moral relativism, although there is some of that, but out of a sense of moral agnosticism. They just do not know what to think about morality. Moreover, they feel little or no responsibility to or for others. In the end, morality is essentially a matter personal feeling. Most of life seemed to be lived in an amoral space where life is a matter of personal cost/benefit, psychological impact, and feeling. The emotivism that Alasdair MacIntyre so famously interrogated is on full display (MacIntyre 1981). What is particularly striking for this theological investigation, is that a significant number of young adults claim that this vision is based on religion, God and/or the Bible. ${ }^{14}$

So, what does Trump as mirror for the church tell us about American Christianity? In light of the results of the National Study of Youth and Religion, it should be unsurprising that so many Christians

12 What is striking is that among the youth, social service is absent, even among mainline churches that stress social service over confessionalism. Political activism was also low among religious right youth.

13 See the classic treatment of this by (Taylor 1985).

14 Upon first encountering this study I found these claims hard to believe. Having now taught a "values and ethics" course for some time to first year undergraduates at a large university in what is regarded as a vibrant religious enclave (in northern Utah) I see this firsthand. 
endorse the politics and culture Trump embodies. For it is clear that American Christianity by and large is not forming people in a meaningful alternative. ${ }^{15}$

\subsection{Incomplete Catechesis}

At this point it is tempting to conclude by suggesting that an ecclesial ethic along the lines of that advocated by Stanley Hauerwas, among others, is what is needed. That what is needed is a more robust theological vision that embraces a distinctive Christian identity-a vision that in contrast with the moralistic therapeutic Deism exposed by the NSYR actually reflects the difference Christ makes in the world. While I have done this elsewhere (Bell 2014), I fear that an honest look in the mirror that Trump provides suggests that even what I regard as the best political theology falters. It, too, suffers from inadequate formation or what we might call incomplete catechesis.

In this regard, in a recent interview, where much energy is devoted to his emphasis on ecclesial moral formation, largely through the liturgy and exemplification (by saints and communities like L'Arch), noteworthy is Hauerwas' admission that more work needs to be done on the disciplines and practices that shape peaceableness and that pointing to examples is not sufficient (Brock and Hauerwas 2017). This connects with an observation that appears repeated in the book-length interview, namely, that the churches are not doing a particularly good job of enacting disciplines crucial to good moral formation-whether the issue is peaceableness, welcoming persons with disabilities, or sitting with the suffering.

While it would not be fair to put this all on Hauerwas, his recognition that there is more to ecclesial moral formation than emphasizing the works of piety (worship, preaching, prayer, etc.) and the examples of the saints is telling. Far too often, I fear, the theo-political vision he advocates gets reduced by others (perhaps including myself) to "add Eucharist and stir." 16 As if moral formation sufficient to resist the darkness that envelopes us were that simple and straightforward.

For example, Rodney Clapp, a friend and fellow-traveler in this theological journey from whom I continue to learn much, in his recent work New Creation: A Primer on Living in the Time Between the Times picks up on John Climacus' enigmatic claim, that "[p]rayer maintains the equilibrium of the world," to assert that prayer is a powerful practice that rehearses and cooperates with God's creative and redeeming work in the world, an assertion he backs up by explicating the Lord's Prayer (Clapp 2018). I must confess that when I read claims for prayer such as this I find myself conflicted, immediately asking, "what about when prayer does not do this?" After all, history is replete with Christians praying the Lord's Prayer and engaging in all kinds of atrocities. American Christians prayed as they engaged in the slavery of Africans and genocide against Native Americans. German Christians prayed earnestly and sincerely in the 1930s and 40s. American Christians prayed earnestly as they scolded King and clung to Jim Crow. American Christians prayed as they supported Obama's drone wars and we pray today as we embrace Trump. Thus, these kinds of claims are incomplete at best; prayer and worship are powerful practices, and they can be signs and instantiations of the new creation, but not necessarily. What is needed is a thicker account of the practices/disciplines of moral formation that must accompany prayer, if it is to be a means of grace and not a cover for cruelty. After all, as any Christian Peacemaker can tell you, formation as peacemakers may entail prayer and liturgy, but it requires a lot more as well. Put differently, for prayer to be formative in ways that advocates of this ecclesial ethic proclaim, prayer and other works of piety must be part of a wider ecology of disciplines and practices.

15 Note that Christians supporting liberal progressivism and the Democratic party does not represent a genuine alternative. As Badiou notes, reflecting on the 2016 election, Clinton and Trump, while differing stylistically, do not represent a fundamental political difference or choice: they belong to the same world (Badiou 2019, pp. 21-25). As Bacevich suggests, what Americans mistake for politics - the putative rivalry that pitted Democrats against Republicans-amounts to little more than theater. See (Bacevich 2010, p. 32) See also (Bacevich 2018, pp. 410-11).

16 I get this phrase from Amy Laura Hall, who in turn got it from Kara Slade. See (Hall 2015, p. xii). 


\section{What Now? Death and Resurrection of the Church}

Trump is not an alien intrusion in American politics and culture; he is a mirror of that very politics and culture. He is a reflection, as well, of the church in America. As such, he is a sign of the church's failure. More pointedly, Trump's election with crucial support from American Christians signifies that the church in America is dead. What Michael Eric Dyson says of America applies just as well to the church: "Trump is what happens when we become a moral corpse" (Dyson 2017). Or perhaps Trump is proof of one of Hauerwas' more memorable claims, "God is killing the church and we goddamn well deserve it" (Woodward 1993). Or as Luther said, in a more enigmatic vein, "Frogs must have their storks" (Luther 1962).

\subsection{The Death of the American Church}

What Trump reflects, the NSYR makes clear, is not merely the defeat of the church, as though the church was effectively forming persons in a vision and way of life at odds with the culture and politics Trump reflects. It is not even the case the church is being defeated in an attempt to form persons in an alternative culture and politics. As the NSYR suggests, the church is actually succeeding in what it is doing: forming persons in a kind of Deism that, Christian voting patterns suggest, is not out of place in contemporary American culture and politics.

What we are witnessing is the failure of the church; the end of the line; the death of the church. Not literally, of course, for as Stanley Hauerwas has remarked, you cannot kill the Rotary Club. This is to say, residual forms of the church, merrily espousing their moralistic therapeutic Deism, will persist indefinitely, even as their bureaucratic forms continue to mutate, separate and otherwise adapt in response to cultural trends and shifts.

What I mean by the death of the church is something akin to Ephraim Radner's claim that the divided church suffers pneumatic abandonment (Radner 1998). This is to say, the division of the church is a counter-witness to the gospel of such magnitude that the Holy Spirit has taken leave of the divided church. ${ }^{17}$ What Radner asserts in light of the church's division, I am suggesting in light of the church in/of America's embrace of the culture and politics of which Trump is a sign-symptom. ${ }^{18}$

As Radner carefully explicates, this pneumatic abandonment affects the church in all dimensions of its life: its ability to read Scripture, to discern holiness, to pursue vocations, and celebrate the liturgy. About this abandonment, he explains:

[this] does not mean a deprivation of the spiritual gifts and 'fruit' that forms the basis of satisfaction for just persons. It rather is a question of the historical experience of this grace, which 'appears' to rob the object of the Spirit's indwelling of an open apprehension of such presence, love forming itself, as it were, through its own consistent self-questioning. The appearance, however, is not an illusion in this case, because the Spirit's intimate work is accomplished - again, in figural conjunction with Jesus' own life - through the phenomenal assertion of its own distance. (Radner 1998)

Put simply, pneumatic abandonment means that it is much more difficult to see and hear, that is, discern the truth in our midst. Holiness as the marker of Christian visibility is displaced as doctrine and structures move to the center of Christian witness. And, as we have seen in the results of the NSYR, these were not adequate to sustain the faith but eventually give way as Christianity in America transforms into the Gnosticism and realism that enable Christians to embrace the culture and politics that produce Trumps.

17 Radner references Ezekiel 11:23 (Radner 1998, p. 10).

18 Had I the time, I would argue that the two issues are not unrelated. For a work that engages the issues involved in linking church division and ethical issues, see (Root and Buckley 2012). 
Also helpful for grasping the character of this death is Jonathan Lear's work on ethics in the face of cultural devastation (Lear 2006). Lear examines the Crow nation at the end of the 19th century, when it faced the destruction of its life and culture on the reservation.

His work is driven by an enigmatic statement made by Plenty Coups, the last great Crow chief. When interviewed about Crow life, Plenty Coups would not speak of anything that happened after the Crow were confined to a reservation. When asked, he simply said, "After this, nothing happened" (Lear 2006).

Lear painstakingly parses this as a statement of death and in doing so develops a distinction between the commonplace and rather benign claim that a certain way of life has ended and the more final or definitive claim of the death of that life or culture. When one says that a way of life has ended, the implication is that one way of living that life has concluded but that the life itself may continue in another form or forms. The assumption is that the concepts, narratives and practices that constitute and sustain that culture remain intact and available to render a new way of living that life intelligible. So, for example, a connectional ecclesial polity might appeal to its mission statement in order to explain its shift to a federated or even congregational polity or the earliest Christians might appeal to Scripture in accounting for the admission of Gentiles to the young movement.

The death of a culture, on the other hand, involves the loss, absence, or failure of concepts and correlative practices capable of narrating the life, of rendering it intelligible. Death means the loss of intelligibility such that a life no longer makes sense. The subject is dead. "After this, nothing happened." As Lear puts it, the difference is between the question "How shall I, as a Crow, go on?," which assumes the persistence of the identity of "Crow" even as it faces the challenge of adapting to new circumstances and the question, "What shall it mean to go on as Crow?"- a very different question, one that calls into question the possibility of embodying that identity in a way that is recognizable to the previous carriers of that culture (Lear 2006).

Certainly, contemporary American Christianity can be read in terms of the former. Bloom, for example, suggests that we are not so much in a "post-Christian" era (which implies an end) as we are living through a post-Protestant "redefinition" of Christianity (Bloom 2006). No doubt Bloom will find much company among those who reject my claim that the American church is dead. I have mis-interpreted the signs of the times or perhaps overstated the problem, they will say. What we are going through is simply a cultural shift to a new way of understanding Christianity and embodying Christian identities. Or I have misunderstood what Christianity is really about.

But what Trump reflects is no mere cultural transition or adaptation. He reflects an end, a dead end (which, again, he did not initiate but merely reflects). When the body of Christ embraces Nietzsche's values, when it embraces evil, albeit a purported "lesser one," when its political anthem is America First and the scope of its political imagination delimited by the political theater named "Democrats versus Republicans," the name Christian no longer makes sense as a marker for a body that follows Christ as its head, its king (in all that suggests). As the NSYR suggests and the explosion of nones, prodigals and exiles reinforces, ${ }^{19}$ it is not on the way, that is, reflecting the difference Christ makes in the world for the sake of redeeming the world. In other words, it is dead.

\subsection{Embracing Death and Despair}

This is a tough claim to swallow. It is a difficult claim to write. We are tempted to deny it. Indeed, a characteristic of a dead church is endemic ecclesial deception. ${ }^{20}$ Thus, a racially and economically segregated church whose doors (and hearts) are shut to the surrounding community declares itself "the friendly church." A seminary that produces graduates who cannot cogently articulate the meaning of "behold the Lamb of God who takes away the sin of the world" and who have no idea what leadership

19 See (Kinnamon 2007, 2011).

20 The phrase is Radner's (Radner 1998, p. 82). 
entails beyond being nice declares itself to produce excellent parish pastors. Denominational ordination committees congratulate themselves on their excellent work even as their congregations wilt and those members who remain embrace Trump and what he reflects. We consistently fail to see our own failure. $^{21}$

It is hard to get our bearings in part because of a certain theological prejudice that attends Christian eschatology. Because we self-identify with/as the church, we assume that we are on the right side of Providence. When Jesus declares to Peter in the Gospel of Matthew "on this rock I will build my church, and the gates of Hades will not prevail against it," (Matthew 16:18, NRSV) we assume that he was talking to us. After all we know Jesus died for us and God loves us, personally and intimately (recall Bloom's Gnosticism). Our confessions remind us that the Church is of God [that's us!] and will be preserved until the end of time.

We forget that "not everyone who says to me, 'Lord, Lord' will enter the kingdom of heaven" (Matthew 7:21, NRSV). It simply does not register with us that on the Day of Judgment the sheep and the goats are surprised (Matthew 25:31-46). Speaking of the Day of Judgment, we cannot fathom that it might be a day of darkness and not light, of judgment, not vindication. ${ }^{22}$

Perhaps because we have participated too enthusiastically in singing hymns to our own, that is, America's greatness, we cannot imagine the church's proper figure is Israel in exile, under judgment, and that Jeremiah's exhortation to embrace defeat is a word from the Lord for us. ${ }^{23}$

Perhaps because we are too invested in the self-image that, as Hillary Clinton put it, "America has never stopped being great," accepting that defeat, failure, humiliation might be the form of Christ given to us in this time is, perhaps, too much for us to bear. ${ }^{24}$

But what if we do bear it? What if we do take up this cross? The temptation is to despair. After all, if we are willing to embrace Nietzsche's values then perhaps we ought to take to heart his madman's sermon, which proclaimed that God was dead, we had killed him, and that the churches were God's sepulcher (Nietzsche 2001).

Despair may well be the appropriate response to the state the American church is in. Perhaps, as Radner says, following Jeremiah's words to the Israelite exiles, the proper response to the state we are in is to live in this abandonment (Radner 1998). Here is the space for a theologically appropriate despair-despairing of what we have done and what we have left undone. Despair, that is, as an expression of penitence. ${ }^{25}$

\subsection{Endings and New Beginnings: Radical Hope}

Herein lies the path toward hope. For, as Radner also notes, "There is a grace in a dying that is merely and genuinely suffered" (Radner 1998). In this regard, recall that the grave site is also the locus of resurrection. Where God's body is broken, that is the site of new life, new creation, resurrection. (Something I suspect Nietzsche's madman failed to realize). It is precisely in the face of death that God gives the gift of new things, new beginnings, new life. Hope. Thus, Jesus tells his disciples: "Very truly, I tell you, unless a grain of wheat falls into the earth and dies, it remains just a single grain; but if it dies, it bears much fruit. Those who love their life lose it; and those who hate their life in this world will keep it for eternal life" (John 12:24-5. NRSV). And Paul can remind the congregation at Rome, "We do not live to ourselves, and we do not die to ourselves. If we live, we live to the Lord, and if we die, we

21 I include myself in the "we" as I am fully implicated in the condition I describe.

22 See Amos 5:18-24; Malachi 3:2-3.

23 See (Radner 1998, pp. 331, 332, 336). See also (Hall 2017). My thanks to Michael Budde for bringing Hall's essay to my attention.

24 For the HRC quote, see (Glass 2016).

25 I am reminded of Walter Brueggemann's wonderful treatment of what he calls the psalms of disorientation, which include psalms of despair. See (Brueggemann 1986). 
die to the Lord; so then, whether we live or whether we die, we are the Lord's" (Romans 14:7-8 NRSV). Likewise, he boasts to the congregation in Corinth: "I die every day!" (1 Corinthians 15:31 NRSV).

And Luther, famously, declared that the Christian life is nothing else than a daily living out of our baptismal deaths: "Thus a Christian life is nothing else than a daily Baptism, once begun and ever continued. For we must keep at it incessantly, always purging out whatever pertains to the old Adam, so that whatever belongs to the new man may come forth" (Luther 1959).

Having imbibed so deeply from the spring of American individualism, we may be predisposed to read these claims as primarily addressing individuals. But, alas, the church, too, is subject to death and resurrection. John Calvin says this about as well as anyone when he writes:

though the Church differed nothing for a time from a dead man, or at least from one that is maimed, no despair ought to be entertained; for the Lord sometimes raises up his people, as though he raised the dead from the grave: and this fact ought to be carefully noticed, for as soon as the Church of God does not shine forth, we think that it is wholly extinct and destroyed. But the Church is so preserved in the world, that it sometimes rises again from death: in short, the preservation of the Church, almost every day, is accompanied with many miracles. But we ought to bear in mind, that the life of the Church is not without a resurrection, nay, it is not without many resurrections. (Calvin n.d.)

The point is that we need not fear death, even the death of the church, with the hopes, careers, and lives that are bound up in its current forms, because in the face death there is hope: God resurrects, gives new life to the church.

What might this look like? For a hint of what hope might look like in the wake of cultural devastation, let us turn again to Lear's work, this time on radical hope. Lear studies the Crow, and Plenty Coups in particular, because he is convinced that Plenty Coups was successful in leading the Crow through a kind of death and resurrection by means of what he calls radical hope. Lear explains radical hope thus: "What makes this hope radical is that it is directed toward a future goodness that transcends the current ability to understand what it is. Radical hope anticipates a good for which those who have the hope as yet lack the appropriate concepts with which to understand it" (Lear 2006).

Specifically, Plenty Coups was able to "reason at the abyss," in the face of the collapse of Crow civilization, with its attendant loss of a telos and the eclipse of what constituted Crow identity/subjectivity. He was able to think through the "nothing" that happened after the Crow were removed to the reservation, exercising, in particular, imagination and courage to reconstitute Crow identity and practice. Imagination entails an ability to envision and embrace emergent forms and practices suited to the reality one faces, as well as to exercise the practical judgment to discern was is truly emergent as opposed to merely residual or alternative. Courage, in contrast with a "mere optimism," which ignores reality, involves risk-taking when one does not see or understand the future (Lear 2006).

The centrality of grace to Christianity means that radical hope is more a matter of reception and discovery, than planning and construction. It is a matter of discerning what new things God is doing when the new things God is doing exceed our current ability to see or understand. Certainly this entails courage, risk-taking and bearing suffering, as well as practical judgment.

As radical hope, as a new beginning after death, as resurrection, certainly what we look for is more than new cultural forms, as if we needed to update moralistic therapeutic Deism, realism or Gnosticism for a postmodern age.

\subsection{What Does This Look Like?}

What new things is God doing in our midst? When we lift our eyes to the hills, what new forms of church are on the horizon? What might we members of the American church, the church of America, hope for? What does a church in America that is not wedded to America First look like? What might this new life look like? 
I confess I do not know. I am no prophet nor a seer. I am a failed theologian and not much of a Christian. Moreover, I live in a desert, the ruins of a church the Spirit has abandoned, or perhaps it is the slough of despair.

Perhaps these new things, this resurrected church, are already on the horizon or even in our midst in the missional church movement or the emergent church or intentional Christian communities or any of a host of experiments in discipleship that elude mainline recognition.

Whatever shapes and names these new forms take, I expect that they will involve a much fuller catechesis in both works of piety and works of mercy, along with accountability/support, than is commonplace now, perhaps something along the lines of the kinds of formation (involving translation, testimony and detachment) that Kenda Creasy Dean outlines in her reflections on the NSYR. ${ }^{26}$

In pondering future forms of faithfulness, I cannot help but recall an experience I had several years ago when invited to speak at the US Army's Command and General Staff College. As I stood preparing to speak to thousands of soldiers, I was suddenly and involuntarily drawn to a comparison with the church I knew and served. I was struck by both a deep similarity and dissimilarity. Like the church gathered on Sunday morning, it was deeply American in its ultimate commitments. Yet unlike the church gathered on Sunday morning, there was a palpable sense of mission that united the people before me-a mission that was greater than any individual in that room. A mission that was not focused on the self, in sharp contrast with the moralistic therapeutic Deism or narcissistic Gnosticism of the church.

Whatever form a Christianity that is neither Gnostic nor deistic takes in America, I suspect that it will entail a sense of enlistment in a way of life (that is 168 hours a week, not just two or three on a Sunday morning plus maybe an additional hour or so on a week night) that liberates the self from the atomistic individualism that underwrites the culture and politics (and economy) that produces Trumps. It will offer something so compelling that we are drawn out of the grotesque and nihilistic curvatus in se, our being curved in ourselves, that has afflicted us since the Fall, and freed in discovering the gift of others, of giving to and receiving others in serving the common good and renewing communion/community development. ${ }^{27}$

\subsection{In the Meantime}

As we hope, wait, seek, discern, what should we do? What posture or position or discipline(s) might serve as a means of grace for the reception of hope and the new forms it takes? Recall Jeremiah's and Radner's advice: embrace defeat; live in this abandonment as a penitential acceptance of humiliation as the form of Christ given to the American church in these dark times. More specifically, Radner urge that we remain loyal to the church's empty precincts (Radner 1998). For there is grace in dying; the grave is the site of resurrection.

Besides, where would we go? We cannot flee. Breaking off and forming our own righteous remnant or enclave would only replicate and exacerbate the sin of division that Radner exegetes so well, and it would hardly instantiate an interruption of the fractious individualism of American culture and politics that is devoid of charity anyway.

No, in the meantime we bear the death of the church, learning to love as a figuration of Christ's humiliated charity, learning to bear with one another as Christ bears our sin, trusting that such a daily dying, such a giving over to death, is but a prelude to resurrection-to the church's resurrection.

\section{Conclusions}

"This sly and relentless force that moved through the world, this patient and brutal something that people called hope.". - Pam Durban (Durban 1996)

\footnotetext{
26 See especially chapters 6-8 (Dean 2010).

27 For more on this, see (Bell 2014).
} 
Trump's election with crucial support from American Christians signifies that the church in America is dead. Acknowledging this is painful, even brutally so, but it is not a bad thing insofar as confessing sin is really just an opportunity to confess the one who can and will deliver us from sin. Acknowledging death, for the Christian, is always an act of hope in the resurrection. As Radner says, there is grace in dying. Which is to say that while we may not be faithful, God is and God is not done with us. Herein lies our hope.

In this regard I am reminded of the writer Pan Durban's jarring and enigmatic description of hope. Christ is a rough and brutal beast, slouching under the weight of sin's cruelty toward the mount of our redemption. And God is both sly and relentless. Thus, Rowan Williams suggests that faith is about learning to see. Learning to see what we cannot see. Learning to see that there is more going on than we can see (Williams 2016).

In these dark times, it is difficult to see what is coming next. Hannah Arendt, reflecting on hope in dark times, suggests illumination comes not from theories and concepts but from the lives and work of people (Arendt 1968). We need prophets, saints, and seers. Mentors who have walked the stony road through the valley of darkness before.

In our midst are communities who have lived through dark times. In the US in particular, I am reminded of Cornel West's comments after September 11, 2001, that in the face of terrorism, white folks are beginning to feel what African Americans have experienced for generations in America (Morrison and West 2004). In a similar vein, Howard Thurman reflects on the radical hope that sustained an enslaved people in America in dark times:

At the time when the slaves in America were without any excuse for hope and they could see nothing before them but the long interminable cotton rows and the fierce sun and the lash of the overseer, what did they do? They declared that God was not through. They said, "We cannot be prisoners of this event. We must not scale down the horizon of our hopes and our dreams and our yearnings to the level of the event of our lives." So they lived through their tragic moment until at last they came out on the other side, saluting the fulfillment of their hopes and their faith. (Thurman 1956)

Perhaps herein lies a clue as to where radical hope might be found.

I close with a few words I overheard the other day, while hanging out in the ruins of the church: "You know what time it is, how it is now the moment for you to wake from sleep. For salvation is nearer to us now than when we became believers; the night is far gone, the day is near" (Romans 13:11-12, NRSV).

Funding: This research received no external funding.

Acknowledgments: My gratitude to Michael Minch for insightful comments on a draft of this essay.

Conflicts of Interest: The author declares no conflict of interest.

\section{References}

Alexander, Michelle. 2010. The New Jim Crow: Mass Incarceration in the Age of Colorblindness. New York: The New Press.

Arendt, Hannah. 1968. Men in Dark Times. New York: Harcourt, Brace \& World.

Bacevich, Andrew. 2002. American Empire. Cambridge: Harvard University Press.

Bacevich, Andrew. 2010. Washington Rules. New York: Metropolitan Books.

Bacevich, Andrew. 2018. Twilight of the American Century. Notre Dame: University of Notre Dame Press.

Badiou, Alain. 2019. Trump. Medford: Polity Press.

Barna Group. 2016. Religious Beliefs Have Greatest Influence on Voting Decisions. Available online: https: //www.barna.com/research/religious-beliefs-have-greatest-influence-on-voting-decisions/ (accessed on 12 September 2017).

Barsamian, David. 2002. Tariq Ali Interview. Available online: https://progressive.org/magazine/tariq-aliinterview-barsamian/ (accessed on 13 July 2019). 
Bell, Daniel M., Jr. 2014. Behold the Lamb of God Who Does What? Gossiping about Jesus and Giving Our Neighbors the Boney Finger. In Who Do You Say That I Am? Proclaiming and Following Jesus Today. Edited by Michael Root and James J. Buckley. Eugene: Cascade Books, pp. 88-107.

Block, Daniel. 2018. Is Trump Our Cyrus? The Old Testament Case for Yes and No. Available online: https://www.christianitytoday.com/ct/2018/october-web-only/donald-trump-cyrus-prophecy-oldtestament.html (accessed on 13 December 2019).

Bloom, Harold. 2006. The American Religion. New York: Chu Hartley Publishers.

Brock, Brian, and Stanley Hauerwas. 2017. Beginnings: Interrogating Hauerwas. Edited by Kevin Hargaden. New York: Bloomsbury T\&T Clark.

Brueggemann, Walter. 1986. Praying the Psalms. Winona: St Mary's Press.

Calvin, John. n.d. Commentary on Jonah, Micah, Nahum. Grand Rapids: Christian Classics Ethereal Library.

Clapp, Rodney. 2018. New Creation: A Primer on Living in the Time Between the Times. Eugene: Cascade Books.

Clinton, William. 1997. Remarks by the President to the AFL-CIO Biennial Convention. Available online: https: //clintonwhitehouse4.archives.gov/textonly/WH/New/html/19970924-5807.html (accessed on 12 August 2016).

Cohen, Eliot A. 2019. He's No King David. Available online: https://www.theatlantic.com/ideas/archive/2019/12/ donald-trump-modern-day-king-david/602830/ (accessed on 7 January 2020).

Dean, Kenda Creasy. 2010. Almost Christian: What the Faith of Our Teenagers is Telling the American Church. New York: Oxford University Press.

Debord, Guy. 1995. The Society of the Spectacle. Translated by Donald Nicholson-Smith. New York: Zone Books.

Durban, Pam. 1996. Soon. The Southern Review 32: 725-42.

Dyson, Michael Eric. 2017. Tears We Cannot Stop. New York: St Martin's Press.

Gerson, Michael. 2018. The Last Temptation. Available online: https://www.theatlantic.com/magazine/archive/ 2018/04/the-last-temptation/554066/ (accessed on 3 March 2019).

Glass, Nick. 2016. Clinton Takes on Trump: 'America Never Stopped Being Great'. Available online: https://www.politico.com/blogs/2016-dem-primary-live-updates-and-results/2016/02/hillary-clintondonald-trump-slogan-219908 (accessed on 8 January 2019).

Hall, Amy Laura. 2015. Foreword. In Borderline. By Stan Goff. Eugene: Cascade Books, pp. vii-xiii.

Hall, Gary. 2017. Jeremiah 29: A Theological Foundation for Urban Mission? Stone-Campbell Journal 20: 53-62.

Hirschle, Thomas A., James G. Booth, and Leland L. Glenna. 2009. The Link Between Voter Choice and Religious Identity in Contemporary Society: Bringing Classical Theory Back In. Social Science Quarterly 90: 927-44. [CrossRef]

King, Martin Luther, Jr. 1964. Why We Can't Wait. New York: Signet Books.

Kinnamon, David. 2007. UnChristian: What a New Generation Really Thinks about Christianity and Why It Matters. Grand Rapids: Baker Books.

Kinnamon, David. 2011. You Lost Me: Why Young Christians Are Leaving Church and Rethinking Faith. Grand Rapids: Baker Books.

Lear, Jonathan. 2006. Radical Hope: Ethics in the Face of Cultural Devastation. Cambridge: Harvard University Press.

Luther, Martin. 1959. Large Catechism. In The Book of Concord. Translated and Edited by Theodore G. Tappert. Philadelphia: Fortress Press, pp. 357-462.

Luther, Martin. 1962. Temporal Authority: To What Extent It Should be Obeyed. In Luther's Works. Edited by Walther I. Brandt. Philadelphia: Fortress Press, vol. 45, pp. 75-130.

MacIntyre, Alasdair. 1981. After Virtue, 2nd ed. Notre Dame: University of Notre Dame Press.

Marshall, Serena. 2016. Obama Has Deported More People Than Any Other President. Available online: https://abcnews.go.com/Politics/obamas-deportation-policy-numbers/story?id=41715661 (accessed on 22 February 2017).

Morrison, Toni, and Cornel West. 2004. 'We Better Do Something': Toni Morrison and Cornel West in Conversation. Available online: https://www.thenation.com/article/archive/toni-morrison-cornel-west-politics/ (accessed on 10 January 2020).

Nietzsche, Friedrich. 2001. The Gay Science. Edited by Bernard Williams. Translated by Josefine Nauckhoff. New York: Cambridge University Press.

Pew Research Center. 2003. Religion and Politics: Contention and Consensus. Available online: https: //www.pewforum.org/2003/07/24/religion-and-politics-contention-and-consensus/ (accessed on 12 June 2004). 
Radner, Ephraim. 1998. The End of the Church: A Pneumatology of Christian Division in the West. Grand Rapids: William B. Eerdmans Publishing Company.

Root, Michael, and James Buckley, eds. 2012. The Morally Divided Body: Ethical Disagreement and the Disunity of the Church. Eugen: Cascade Books.

Serwer, Adam. 2018. The Cruelty Is the Point. Available online: https://www.theatlantic.com/ideas/archive/2018/ 10/the-cruelty-is-the-point/572104/ (accessed on 18 January 2020).

Smith, Christian, and Melinda Lundquist Denton. 2005. Soul Searching: The Religious and Spiritual Lives of American Teenagers. New York: Oxford University Press.

Smith, Christian, and Patricia Snell. 2009. Souls in Transition: The Religious and Spiritual Lives of Emerging Adults. New York: Oxford University Press.

Smith, Christian, Kari Christoffersen, Hilary Davidson, and Patricia Snell Herzog. 2011. Lost in Transition. New York: Oxford University Press.

Tatum, Sophie. 2017. Trump Defends Putin: 'You Think Our Country's So Innocent?'. Available online: https: //www.cnn.com/2017/02/04/politics/donald-trump-vladimir-putin/index.html (accessed on 7 April 2017).

Taylor, Charles. 1985. Atomism. In Philosophy and the Human Sciences/Philosophical Papers 2. New York: Cambridge University Press, pp. 187-210.

Thurman, Howard. 1956. The Growing Edge. New York: Harper \& Brothers.

Williams, Rowan. 2002. Writing in the Dust. Grand Rapids: William B. Eerdmans Publishing Company.

Williams, Rowan. 2016. What is Christianity? New York: Church Publishing.

Wolf, Zachary B. 2019. Yes, Obama Deported More People than Trump but Context Is Everything. Available online: https://www.cnn.com/2019/07/13/politics/obama-trump-deportations-illegal-immigration/index.html (accessed on 7 January 2020).

Wolfe, Alan. 2003. The Transformation of American Religion: How We Actually Live Our Faith. New York: Free Press. Woodward, Kenneth L. 1993. Dead End for the Mainline? Available online: https://www.newsweek.com/deadend-mainline-192610 (accessed on 14 December 2019).

(C) 2020 by the author. Licensee MDPI, Basel, Switzerland. This article is an open access article distributed under the terms and conditions of the Creative Commons Attribution (CC BY) license (http://creativecommons.org/licenses/by/4.0/). 